\title{
Whitebark pine encroachment into lower- elevation sagebrush grasslands in southwest Montana, USA
}

\author{
Sarah J. Flanary ${ }^{*}$ (I) and Robert E. Keane
}

\begin{abstract}
Background: Projections for the future health and abundance of whitebark pine (Pinus albicaulis Engelm.) populations in western North America are dire. Not only has the species been declining due to the combined effects of fire exclusion policies, mountain pine beetle (Dendroctonus ponderosae Hopkins 1902) outbreaks, and white pine blister rust (Cronartium ribicola J.C. Fisch), many are predicting that climate change will amplify these effects and whitebark pine habitat may be lost in many areas. One method to evaluate the validity of future predictions is to examine current migration patterns of whitebark pine into surrounding non-forested areas. In this paper, we documented the findings of a case study surveying the encroachment of whitebark pine into adjacent lower-elevation sagebrush grasslands and higher-elevation subalpine meadows in southwestern Montana, USA.

Results: We found abundant evidence of whitebark pine trees $\left(>40\right.$ trees ha ${ }^{-1}$ ) in sagebrush grasslands below the mature seed source, but there was no evidence of any whitebark pine regeneration in subalpine meadows above the seed-source stand.

Conclusions: These results are in stark contrast to the findings of statistical modeling studies that predict that whitebark pine will expand into higher-elevation areas as a response to climate change. We believe that the reason for this low-elevation encroachment may be in response to fire exclusion rather than climate change. Although observations in this case study are for a limited geographic area, they do serve to illustrate the complexity of predicting ecological responses of tree species to climate change.
\end{abstract}

\section{Resumen}

Antecedentes: Las proyecciones para la salud y abundancia de poblaciones de pino de corteza blanca (Pinus albicaulis Engelm.) en el Oeste de Norteamérica, son críticas. No solo esta especie ha declinado debido a los efectos combinados de políticas de exclusión del fuego, estallidos del escarabajo de pinos de montaña, y ataques del hongo-roya del pino blanco (Cronartium ribicola J.C. Fisch), sino que también se ha predicho que el cambio climático amplificará esos efectos, y que el pino de corteza blanca puede desaparecer de muchas áreas. Un método para evaluar la validez de predicciones a futuro, es examinando los patrones de migración actuales hacia aquellas áreas no forestadas. En este trabajo, documentamos los resultados de un caso de estudio que relevó el incremento del pino de corteza blanca en áreas adyacentes de pastizales dominados por artemisa (sagebrush grasslands) y de humedales subalpinos de altura en el sudoeste de Montana, EEUU.

(Continued on next page)

* Correspondence: sarah.j.flanary@usda.gov

USDA Forest Service, Rocky Mountain Research Station, Missoula Fire

Sciences Laboratory, 5775 Highway 10 West, Missoula, MT 59808, USA 
(Continued from previous page)

Resultados: Encontramos abundante evidencia de árboles de pino de corteza blanca (>40 árboles ha ${ }^{-1}$ ) en pastizales dominados por artemisa, en áreas más bajas que las proveedoras de fuentes de semillas provenientes de árboles maduros, pero no se encontró evidencia de regeneración de esta especie en los humedales subalpinos, en elevaciones superiores a los rodales proveedores se semilla.

Conclusiones: Estos resultados se contraponen totalmente con aquellos derivados de modelos estadísticos que predicen que el pino de corteza blanca se expandirá hacia áreas más elevadas como respuesta al cambio climático. Creemos que esta expansión hacia áreas más bajas puede deberse más a una respuesta a la exclusión del fuego que al cambio climático. Aunque las observaciones en este estudio de caso son para un área geográfica limitada, sirven para ilustrar la complejidad de predecir respuestas ecológicas de especies arbóreas al cambio climático.

\section{Abbreviations}

BA: Basal Area $\left(\mathrm{m}^{2} \mathrm{ha}^{-1}\right)$

CBH: Canopy Base Height (m)

DBH: Diameter at Breast Height $(1.37 \mathrm{~m}$ above groundline; $\mathrm{cm})$

\section{Introduction}

The combined impacts of fire exclusion policies (Keane 2001), mountain pine beetle (Dendroctonus ponderosae Hopkins) outbreaks (Millar et al. 2012), and white pine blister rust (Cronartium ribicola J.C. Fisch) infections (Keane et al. 2012) have resulted in a rapid decline of whitebark pine (Pinus albicaulis Engelm.) forests in western North America over the last several decades (Arno 1986; Kendall and Keane 2001; Goeking and Izlar 2018). Equally distressing are the projected continuing declines in these iconic forests because of future changes in climate (Warwell et al. 2007; Chang et al. 2014). It is well known that future warmer and drier climates could result in increases in the frequency of wildland fire (Flannigan et al. 2009; Abatzoglou and Williams 2016; Schoennagel et al. 2017) and mountain pine beetle outbreaks (Carroll et al. 2003; Wong and Daniels 2016), but it is also speculated that it will also increase white pine blister rust infections (Landguth et al. 2017; Wyka et al. 2018), thereby perhaps exacerbating the current whitebark pine decline (Keane et al. 2017). Many statistical modeling studies have shown significant reduction in the biophysical conditions that define suitable whitebark pine habitat over the next century (Warwell et al. 2007; Chang et al. 2014). Historically, whitebark pine forests comprised about 10 to $15 \%$ of the upper subalpine zone of the US northern Rocky Mountains (Arno and Weaver 1990), but future projections for these iconic forests suggest that they may inhabit as little as 0.5 to $7.0 \%$ by 2070 to 2100 (Hansen and Phillips 2015).

There are basically three modes of response to climate change for tree species in western North America: modification, contraction, and expansion (synonymous with encroachment for the purpose of this paper) (Keane et al. 2018). A species may increase or decrease in productivity or abundance in situ within its current range due to climate change (Ashton 2010) ("modification"). The species could also potentially decline in parts of its range where conditions change enough to become inhospitable to that species (Allen et al. 2010) ("contraction"). And lastly, the species could migrate to new areas that are more conducive for establishment and growth (Johnstone and Chapin 2003) ("expansion;" or "encroachment" as used in this paper). In reality, many tree species will respond to future climates via all three modes. Conventional wisdom and statistical modeling have predicted that whitebark pine will experience reductions throughout its current range over the next century and experience major reductions in populations within warmer, drier climates (Koteen 2002; Warwell et al. 2007; Chang et al. 2014), but some studies anticipate possible increases in productivity within their core range and possible expansion into nonforested areas at higher elevations (Loehman et al. 2011; Hansen et al. 2016; Keane et al. 2018). Given the complex feedbacks and interactions between climate, biophysical environment, disturbance, and tree species (Matthews et al. 2011; Iglesias et al. 2015; Schneiderman et al. 2015; Singer et al. 2016), the challenge then is to determine the validity of predictions from expert opinions and analyses by measuring early responses of whitebark pine to the changing climate. The detection of migration patterns of a tree species into new environments may provide information on the impacts of climate change on species response and validate existing empirical and simulation modeling study results (Belotelov et al. 1996; Dullinger et al. 2004).

The objective of this case study was to document the encroachment (local expansion of species into new habitats) of whitebark pine (Fig. 1) into both lower elevation sagebrush grassland areas and upper elevation subalpine meadows that are directly adjacent to mature, cone-bearing whitebark pine stands, which might provide seeds for dispersal into the two non-forest settings. We sampled seedling, sapling, and mature tree densities by species on three study sites in southwestern Montana, USA, where we found evidence of encroachment either into the upper subalpine meadow or lower sagebrush grasslands. 


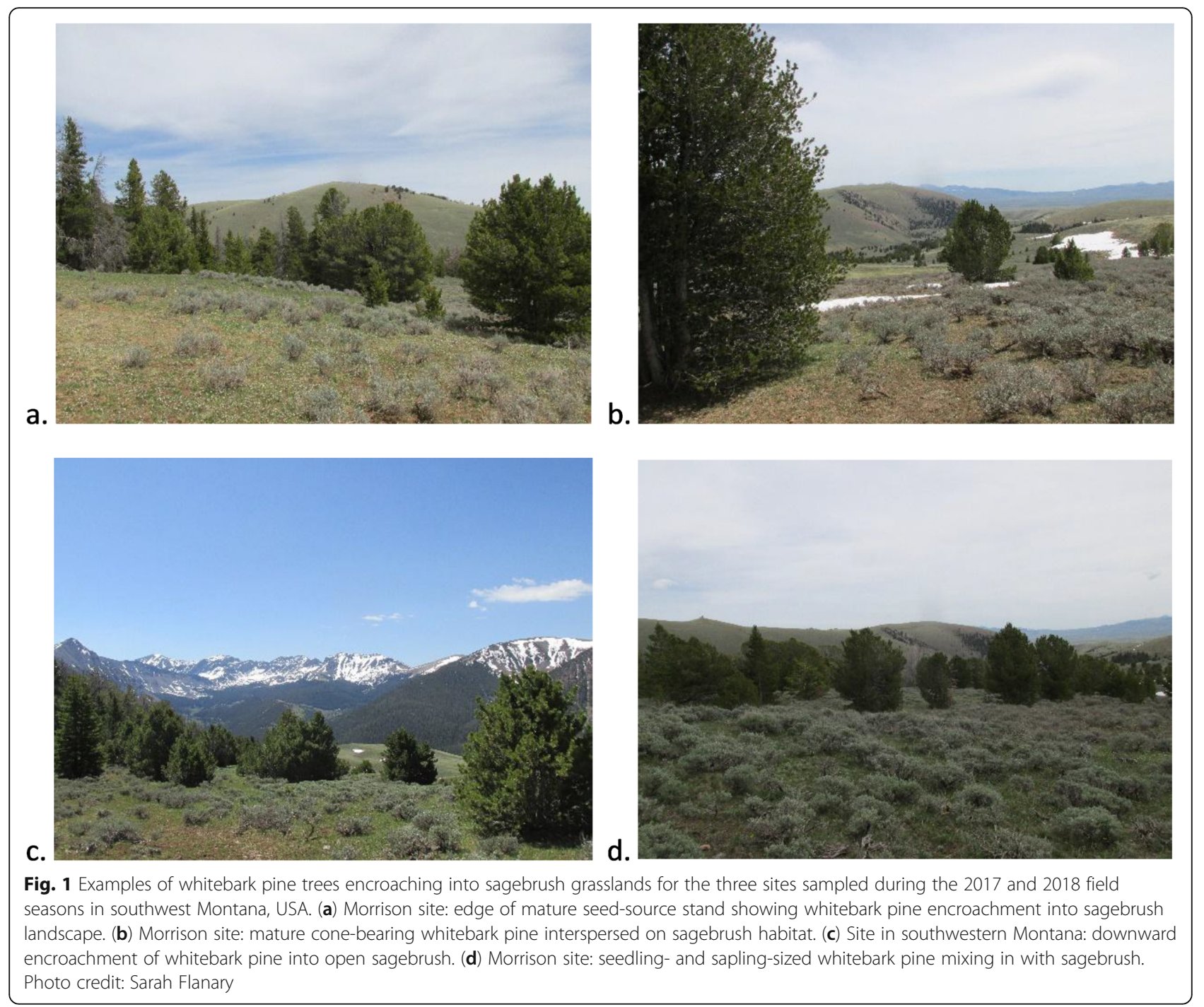

\section{Methods}

\section{Study area}

The Tendoy and Beaverhead mountain ranges of southwestern Montana, USA, served as the study area in this project (Fig. 2). Lower elevational lands within this area contain mountain big sagebrush (Artemisia tridentata Nutt. ssp. vaseyana [Rydb.]) grasslands intermixed with dry Douglas-fir (Pseudotsuga menziesii [Mirb.] Franco) and lodgepole pine (Pinus contorta Douglas) forests (Pfister et al. 1977; Larson 2009), while the upper elevation lands contain subalpine meadows and grasslands with forest patches of whitebark pine, limber pine (Pinus flexilis James), subalpine fir (Abies lasiocarpa [Hook] Nutt.), Engelmann spruce (Picea engelmannii [Parry] Engelm.), lodgepole pine, and Douglas-fir. Mountain big sagebrush lands had a mean pre-settlement fire interval between 25 to 40 years, but fire suppression, elimination of Native American burning, and livestock grazing in these areas have decreased the fire frequencies and increased the amount of dense-canopy mountain big sagebrush (Arno and Gruell 1983; Lesica et al. 2007).

Whitebark pine forests are usually found above 2400 $m$ elevation above MSL (mean sea level) in southwest Montana (Arno and Hoff 1990). Extensive reconnaissance trips into these areas found several sites that were experiencing whitebark pine encroachment where mature whitebark pine forests are adjacent to sagebrush grasslands below in elevation, and to subalpine meadows at the same and at higher elevations. We sampled only three of these areas (Figs. 1,2). Mountain big sagebrush, which inhabits several million hectares within southwest Montana where the study area is located, is generally considered to be self-perpetuating in the absence of fire. However, current imagery and data show that whitebark pine has been encroaching into sagebrush habitat, as verified by reconnaissance trips into these areas (Westoby et al. 1989; Laycock 1991; Lesica et al. 2007; Figs. 1, 3). 


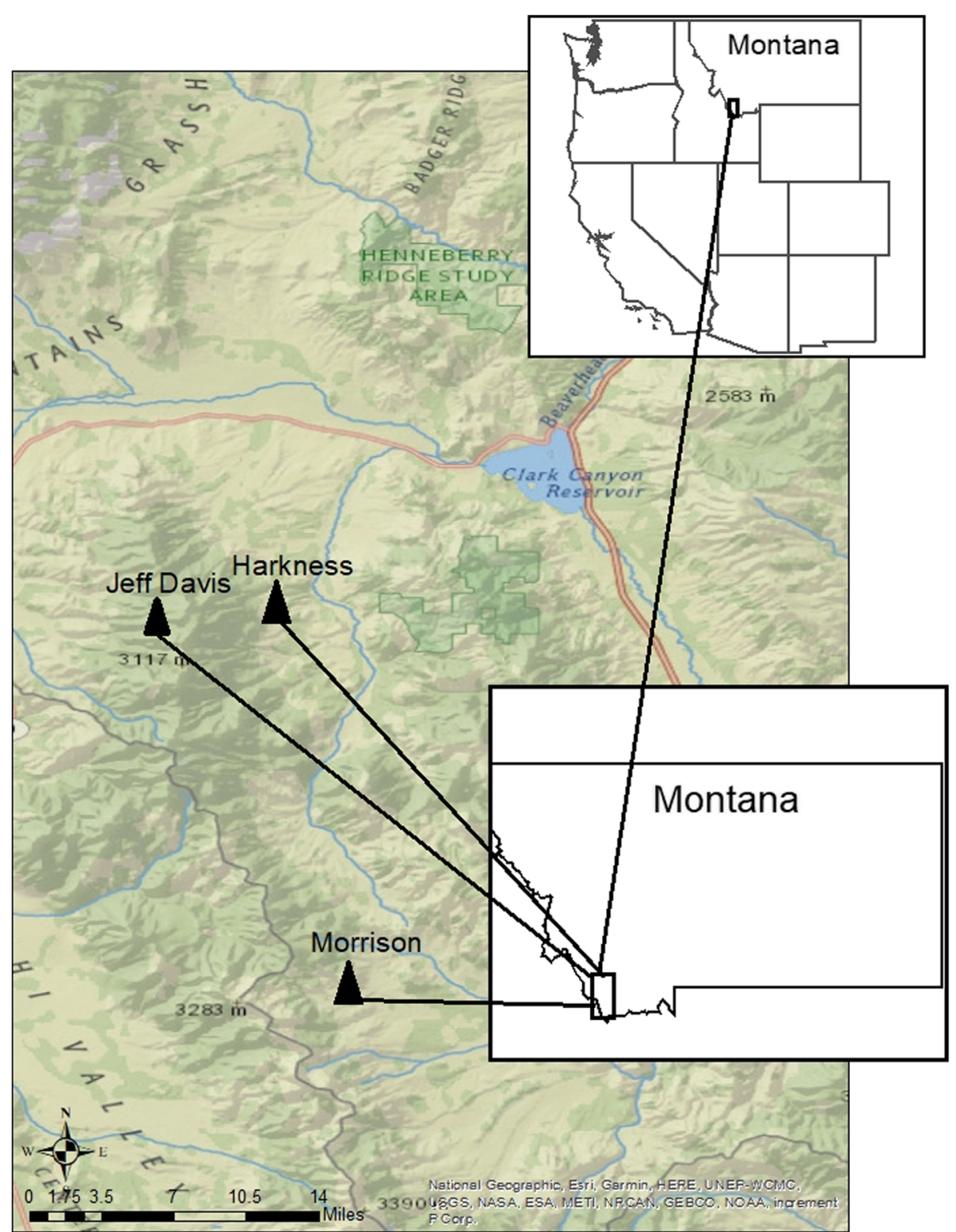

Fig. 2 Locations of the three sites sampled during the 2017 and 2018 field seasons in southwest Montana, USA, study area: Harkness, Jeff Davis, and Morrison sites

\section{Field sampling}

Sites in this study were chosen opportunistically by driving and hiking throughout the study area and finding those areas that displayed possible whitebark pine encroachment either uphill into subalpine grasslands or downhill into sagebrush grasslands (Fig. 1). Cones were examined within the mature seed-source stands and within the general area of each site to verify that the mature trees were whitebark pine rather than limber pine, as both species are found in southwest Montana and can be difficult to distinguish from each other without cones. Later in the project we located aerial survey imagery from the 1950s and compared it to current aerial products to provide further confirmation of encroachment (Fig. 3). We selected three sample sites (Fig. 2) because each had a mature whitebark pine stand available as a seed source and non-forested areas of at least 100 $\mathrm{m}$ above and $100 \mathrm{~m}$ below that mature stand (Fig. 4, Table 1). Unfortunately, the Harkness and Morrison sites were the only sites that had both an upper and lower non-forested area.

At each sampling site, we established five macroplots along a transect established across the width of the mature seed-source stands as near to the center of the stand as possible. The transect was perpendicular to the slope so that each plot was roughly at the same elevation 
(a) Harkness 1953

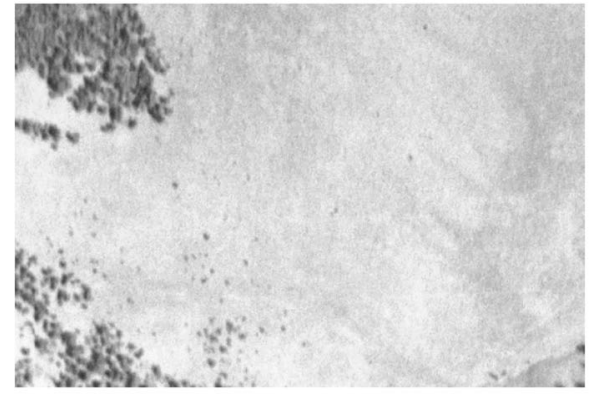

(c) Jeff Davis 1953

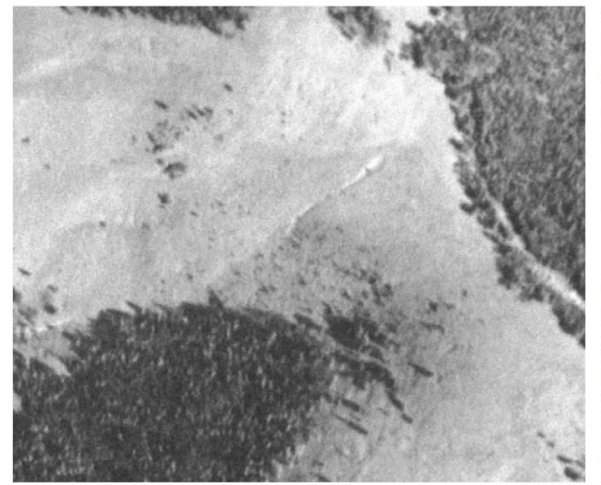

(e) Morrison 1953

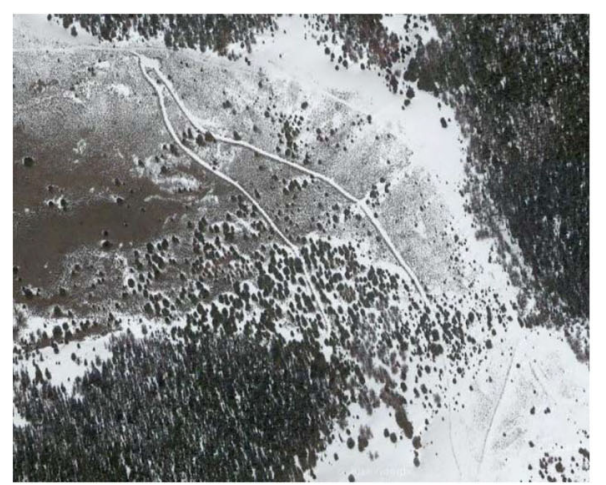

(b) Harkness 2018

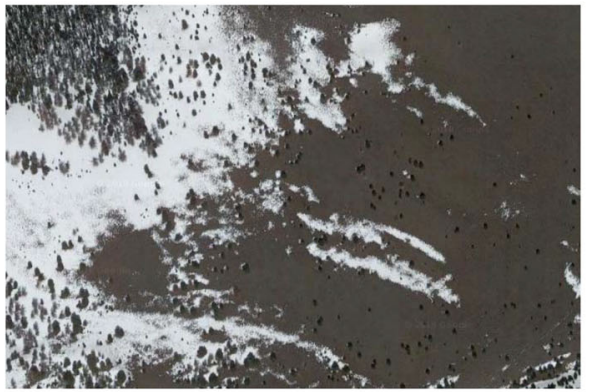

(d) Jeff Davis 2018

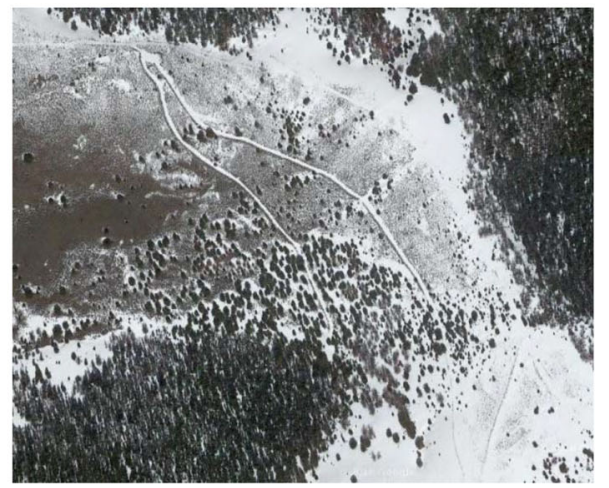

(f) Morrison 2018

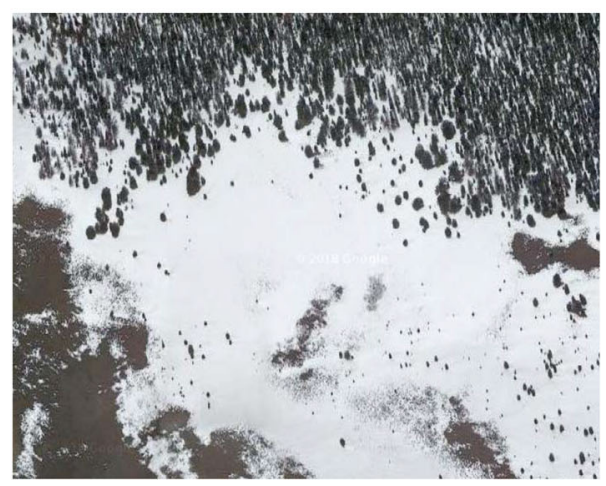

Fig. 3 Historical (1953 to 1954) and current (2018) aerial photographs showing both upper and lower forest margins at the three sites sampled during the 2017 and 2018 field seasons in southwest Montana, USA: (a) Harkness 1953, (b) Harkness 2018, (c) Jeff Davis 1953, (d) Jeff Davis 2018, (e) Morrison 1953, and (f) Morrison 2018. Encroachment is evident in the 2018 photos. Data available from the US Geological Society, USGS Aerial Single Frame Archive, at earthexplorer.usgs.gov

(Fig. 4). Macroplots were equally spaced within the mature stands and were located away from roads or visible disturbances. As these mature stands encompassed variable-sized areas, separations between the macroplots were adjusted to the width of each mature stand along the mid-elevation of the stand (Fig. 4). Macroplots were $400 \mathrm{~m}^{2}$ circular fixed-area plots within which the species, DBH (diameter at breast height, $1.37 \mathrm{~m}$ high), height $(\mathrm{m})$, crown base height $(\mathrm{CBH}, \mathrm{m})$, white pine blister rust presence, and status (live, dead) of all live and dead trees greater than $10 \mathrm{~cm}$ DBH were measured. Within each macroplot, we established a $40 \mathrm{~m}^{2}$ circular microplot at the center of the macroplot to tally all trees less than $10 \mathrm{~cm}$ DBH but taller than $1.37 \mathrm{~m}$ into species and $2 \mathrm{~cm} \mathrm{DBH}$ classes ( 0 to $2 \mathrm{~cm}, 2$ to $4 \mathrm{~cm}$, etc.), and to visually estimate height and $\mathrm{CBH}$ for each $\mathrm{DBH}$ class. Seedlings (trees $<1.37 \mathrm{~m}$ tall) were tallied within microplots by species and $25 \mathrm{~cm}$ height classes (Lutes et al. 2006). We also recorded various stand-level attributes, such as elevation, aspect, slope, and habitat type (Pfister 


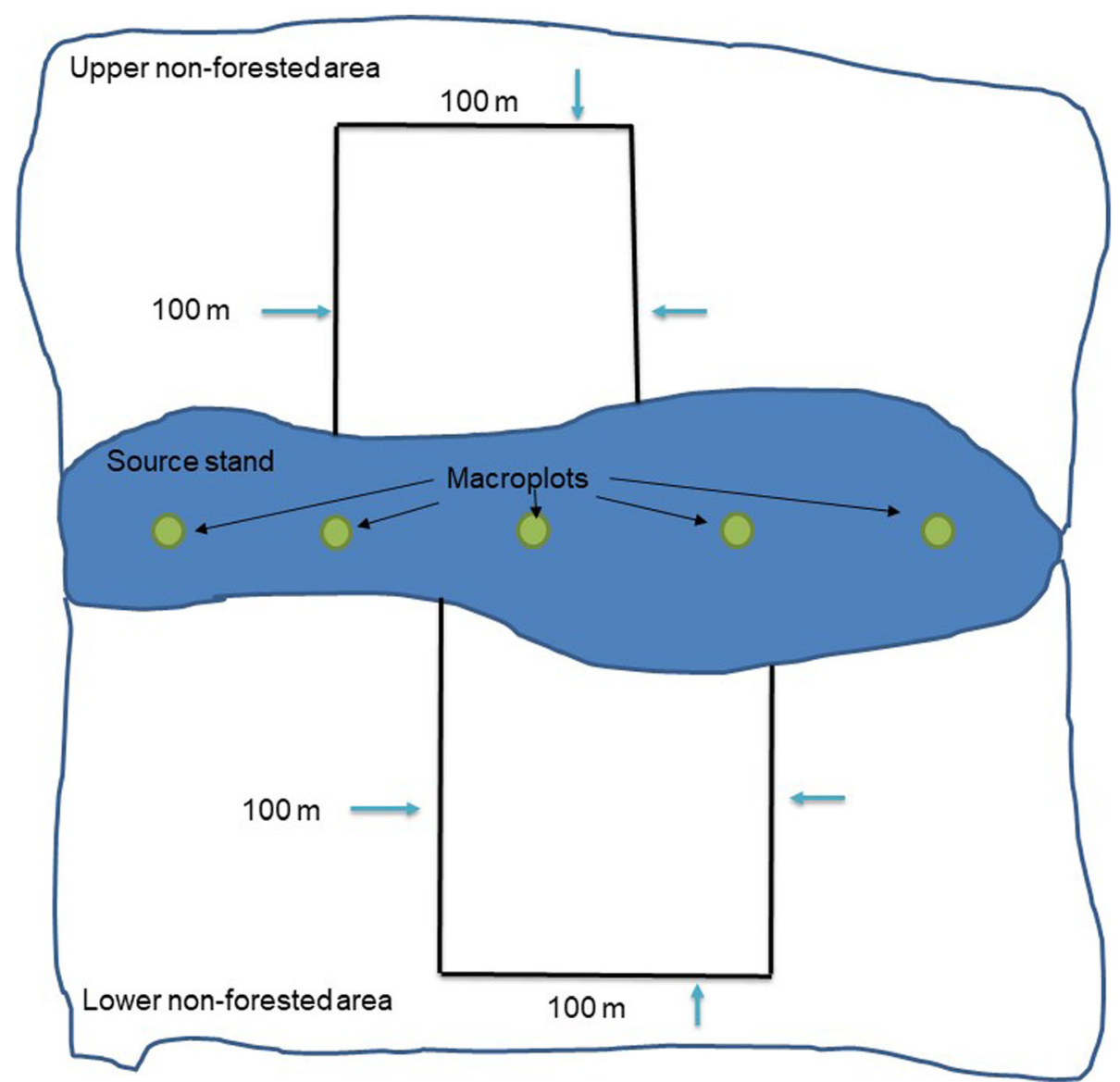

Fig. 4 Schematic of the sampling layout installed at each sample site during the 2017 and 2018 field seasons in southwest Montana, USA. Macroplots were established perpendicular to the slope along the same elevation, and distances between macroplots were adjusted based on the width of the mature stand. The final number of macroplots installed was based upon the width of the seed-source stand, with a minimum requirement of four plots per site. We established at least one belt transect above and below the seed-source stand that was at least $100 \mathrm{~m} \times$ $100 \mathrm{~m}$, and we sampled all whitebark pine trees within these belt transects

et al. 1977) using standardized protocols (Jensen et al. 1994; Lutes et al. 2009).

At the lower and upper edges of the seed-source stand, we used Global Positioning Systems to install one $100 \mathrm{~m}$ belt transect running downhill into the sagebrush grassland and uphill into the subalpine meadow (Fig. 4). Each belt transect was approximately 100 meters wide and at least 100 meters long, following the shape of the stand (Fig. 4). Within these belt transects, we tallied all whitebark pine seedlings $(<1.37 \mathrm{~m}$ tall $)$ by $25 \mathrm{~cm}$ height classes. For all trees above $1.37 \mathrm{~m}$ tall, we recorded species and measured $\mathrm{DBH}$, height, $\mathrm{CBH}$, percent crown killed by blister rust, and age. We also recorded GPS coordinates for these trees. As whitebark pine trees are commonly found growing together from Clark's nutcracker (Nucifraga columbiana Wilson 1811) caches (Tomback 1978), the number of trees present at each cache was also recorded. Age was estimated for trees above $1.37 \mathrm{~m}$ in height within the belt transects from increment cores that were extracted as close to ground level as possible. Rings were easily counted in the field due to the vigorous growth of the whitebark pine trees and the recent migration of these trees was validated by comparing historical photos to existing field conditions. We found no whitebark pine trees or regeneration in the Harkness or Morrison subalpine meadows.

\section{Results}

Mountain pine beetle and white pine blister rust had reduced live trees in all three seed source stands (2\% mortality at Harkness and 60\% at Jeff Davis; Table 1), yet there appeared to be enough living seed trees to provide sufficient seed for whitebark pine regeneration (basal area $>15 \mathrm{~m}^{2} \mathrm{ha}^{-1}$; McKinney 2004). We found that 203 of the 758 trees sampled in the macroplots showed signs of white pine blister rust, although only 60 of the 758 sampled trees had visual identifiers of rust on more than $3 \%$ of their stems and branches. 
Table 1 Description of the three sample sites where data was collected during the 2017 and 2018 field seasons in southwest Montana, USA, to examine whitebark pine encroachment into sagebrush grasslands. Mature trees are those trees above $10 \mathrm{~cm}$ diameter at breast height (DBH) while saplings are below $10 \mathrm{~cm}$ $\mathrm{DBH}$ and seedlings are below $1.37 \mathrm{~m}$ tall. BA is basal area of all tree species and DD is decimal degrees. All tree density values are trees per hectare. No regeneration of whitebark pine or any other conifer species occurred in the upslope subalpine meadows. No other species were found in the non-forest areas, except for five Douglas-fir trees at the Harkness sagebrush site

\begin{tabular}{|c|c|c|c|}
\hline & \multicolumn{3}{|l|}{ Sample sites } \\
\hline & Harkness & Morrison & Jeff Davis \\
\hline Latitude (DD) & 44.88536 & 44.62069 & 44.87296 \\
\hline Longitude (DD) & -113.098 & -113.044 & -113.149 \\
\hline Elevation (m) & 2503 & 2659 & 2658 \\
\hline Aspect (azimuths) & 142 & 84 & 290 \\
\hline Slope (\%) & 13 & 14 & 13 \\
\hline Rainfall (cm) & 64 & 65 & 65 \\
\hline Live mature $\mathrm{BA}\left(\mathrm{m}^{2} \mathrm{ha}^{-1}\right)$ & 17.6 & 25.6 & 14.3 \\
\hline Dead mature BA $\left(\mathrm{m}^{2} \mathrm{ha}^{-1}\right)$ & 2.3 & 0.6 & 20.6 \\
\hline Area belt transect $\left(\mathrm{m}^{2}\right)$ & 14865 & 28800 & 2555 \\
\hline \multicolumn{4}{|c|}{ Whitebark pine tree density $\left(\right.$ trees $\mathrm{ha}^{-1}$ ) in mature seed-source stand } \\
\hline Mature trees & 440 & 389 & 716 \\
\hline Saplings & 263 & 289 & 1005 \\
\hline Seedlings & 2119 & 0 & 3927 \\
\hline \multicolumn{4}{|c|}{ Other conifer tree density (trees ha ${ }^{-1}$ ) in mature seed-source stand } \\
\hline Mature trees & 4 & 12 & 25 \\
\hline Saplings & 78 & 6 & 6 \\
\hline Seedlings & 124 & 0 & 2245 \\
\hline \multicolumn{4}{|c|}{ Whitebark pine tree density (trees ha ${ }^{-1}$ ) in sagebrush grasslands } \\
\hline Mature trees & 112 & 10 & 31 \\
\hline Saplings & 148 & 49 & 516 \\
\hline Seedlings & 41 & 11 & 246 \\
\hline
\end{tabular}

While we found abundant whitebark pine in the sagebrush grassland belt transects, there was no whitebark pine regeneration in the subalpine meadow belts above the Harkness or Morrison mature seed-source stands (there was no subalpine meadow associated with the Jeff Davis site). Whitebark pine densities in the sagebrush grassland belt transects ranged from 68 per hectare $(9$ seedlings, 50 saplings, and 9 mature trees) at the Morrison site, to 583 per hectare ( 31 seedlings, 521 saplings, and 31 mature trees) at the Jeff Davis site (Table 1). Whitebark pine was essentially the only conifer species invading the sagebrush grassland, although we did find five small Douglas-fir saplings at the Harkness site.

All sagebrush areas showed a high number of younger whitebark pine trees present and no trees of other species (Fig. 5). The apparent decline in numbers of seedlings and saplings for the last two decades is primarily a sampling artifact because age was only determined for trees at least $1.37 \mathrm{~m}$ in height (we did not age seedlings). When seedling data were summarized for all microplots, we found decreasing numbers in the smaller height classes (Fig. 6). As seedlings were not sampled for age, we were unable to definitively assign them to age categories, but given whitebark pine's predilection for slower height growth (Arno and Hoff 1990; Keane et al. 2007) and the openness of the sagebrush grassland, we assumed that the measured seedlings represented recent encroachment $(<40 \mathrm{yr})$. Sapling whitebark pine ages spanned the entire range of the fire exclusion era (last 100 years) with most saplings $(>80 \%)$ established 20 to 50 years ago, or from 1950 to 2000 (Fig. 5). The recent encroachment of whitebark pine seedlings and saplings is corroborated by aerial photos (Fig. 3).

\section{Discussion}

In this limited case study, we found that whitebark pine encroachment into non-forested areas only occurred downslope into the sagebrush grasslands rather than upslope into the subalpine meadows. This finding suggests that conventional wisdom and the findings of some species distribution modeling studies may be incorrect in their future projections within the study area. We found that not only were substantial amounts of whitebark pine regenerating downslope in the sagebrush grasslands, but the sampled individual trees were healthy and thriving as evidenced by the large height growth increments, pitch exudations from growth cracks at branch origins near the bole, and large diameters for the young tree ages. Some of the young trees were producing numerous cones at an early age $(<50 \mathrm{yr})$, which is in contrast to the first cone production ages of 60 years documented by Arno and Hoff (1990). Moreover, we found that this encroachment occurred over the last 100 years and did not occur as a pulse but rather as a gradual increase as evidenced by the wide span in ages (Fig. 5) and sizes (Fig. 6) of whitebark pine trees in the nonforested area.

We did not observe any subalpine fir or Engelmann spruce encroachment into either the sagebrush grasslands or the subalpine meadows. We also found abundant nonserotinous lodgepole pine and Douglas-fir seed-source stands adjacent or near $(<500 \mathrm{~m})$ the sagebrush grassland belt transects on all three sites, but found few of these tree species within the belt transects: we found five Douglas-fir trees within the Harkness sagebrush grassland belt transect. The only tree species successfully populating and thriving in the sampled sagebrush grasslands was whitebark pine. While we did not sample additional sites because of time and funding issues, we are sure that there are other sites in this expansive area where whitebark pine encroachment is occurring. We also observed many areas 


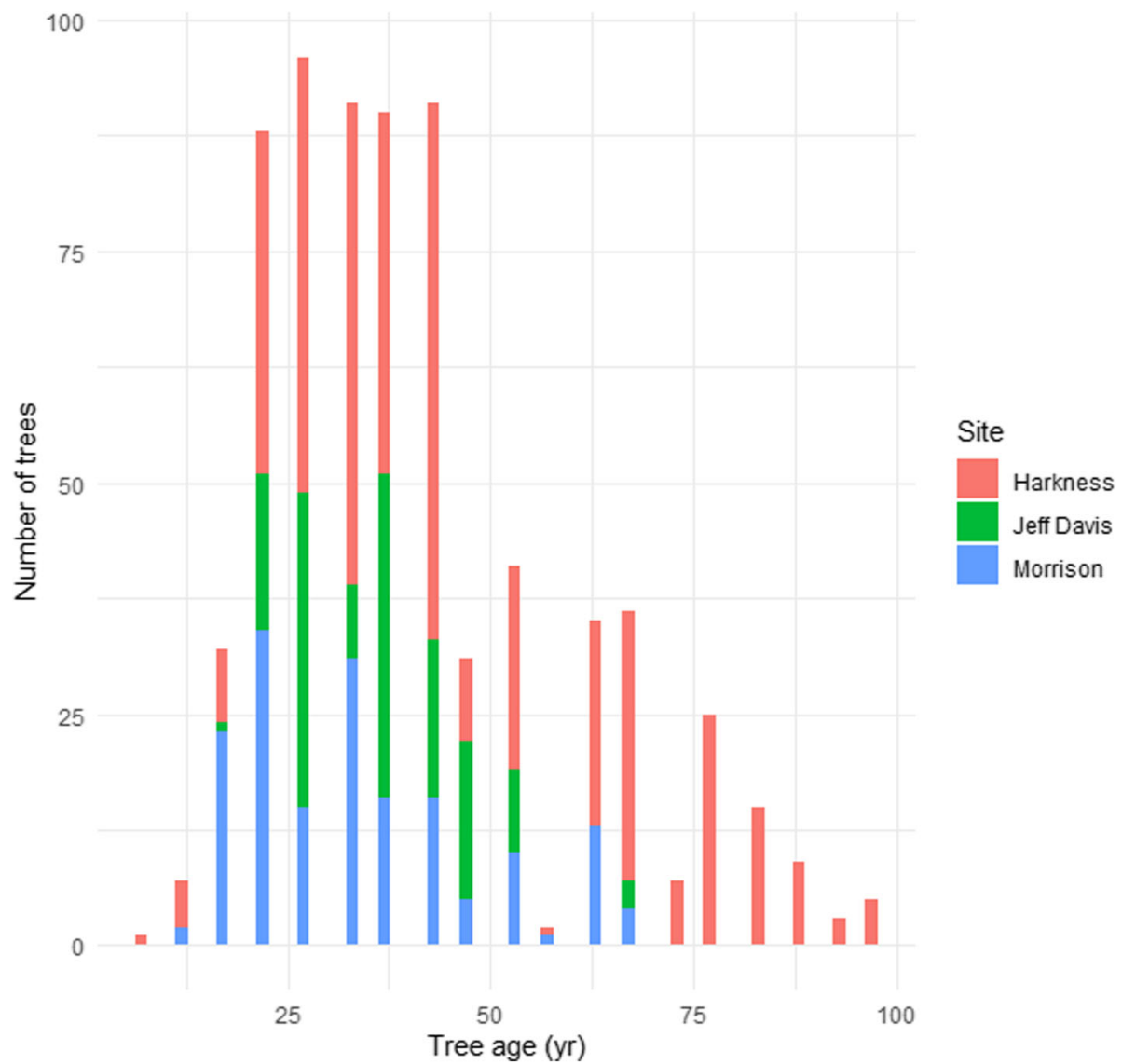

Fig. 5 Count data (number $\mathrm{ha}^{-1}$ ) and field estimated ages (yr) for sapling $(<10 \mathrm{~cm}$ diameter at breast height [DBH]) and mature $(>10 \mathrm{~cm} \mathrm{DBH})$ whitebark pine trees sampled within the 1 ha lower sagebrush grassland belt transects sampled along three sited during the 2017 and 2018 field seasons in southwest Montana, USA

in the study region where whitebark pine forests bordered sagebrush grasslands with no detectable encroachment. Moreover, we failed to detect this phenomenon outside of southwest Montana.

The explanation for this limited downward migration of whitebark pine remains a mystery. We speculate that the lack of fire in the southwestern Montana sagebrush grasslands over the fire exclusion era, perhaps since 1860 (Heyerdahl et al. 2006), has allowed whitebark pine to expand its range downward in elevation, as has been documented by Arno et al. (1993) for the Bitterroot Valley in Montana, but this doesn't explain why other tree species in the area failed to migrate into the non-forested areas. Whitebark pine seeds are dispersed by a bird, the Clark's nutcracker (Tomback 1998), which can disperse seeds great distances $(>10 \mathrm{~km})$, allowing whitebark pine a dispersal advantage over wind-dispersed species. However, 90 years should be more than sufficient to allow wind to disperse seeds of whitebark pine's competitors into sagebrush grasslands. Still more compelling is that few studies have identified sagebrush grasslands as reliable or common nutcracker caching habitat (Tomback 1982, 1986) or suitable whitebark pine regeneration environments (Arno and Hoff 1990). Sagebrush has been known to facilitate some pines (Callaway et al. 1996), and many whitebark pine sites have a sagebrush component (Arno 2001), but whitebark pine encroachment into sagebrush grasslands has never before been documented. Mycorrhizae may also play a role in the regeneration of whitebark pine in this arid area by allowing access to more soil water (Lonergan et al. 2013), but many of the other tree species in the area often share the same beneficial mycorrhizae (Mohatt et al. 2008).

\section{Implications}

Results from this limited case study of three sites in western Montana, USA. indicate that we still have an incomplete understanding of what will drive tree regeneration and growth dynamics into our uncertain future. We can anticipate possible responses of tree species such as whitebark pine to a warming climate, but it will always be difficult to determine the primary change agents or factors that influence future species populations because of the complex interactions among changes in disturbance, climate, vegetation, and land 


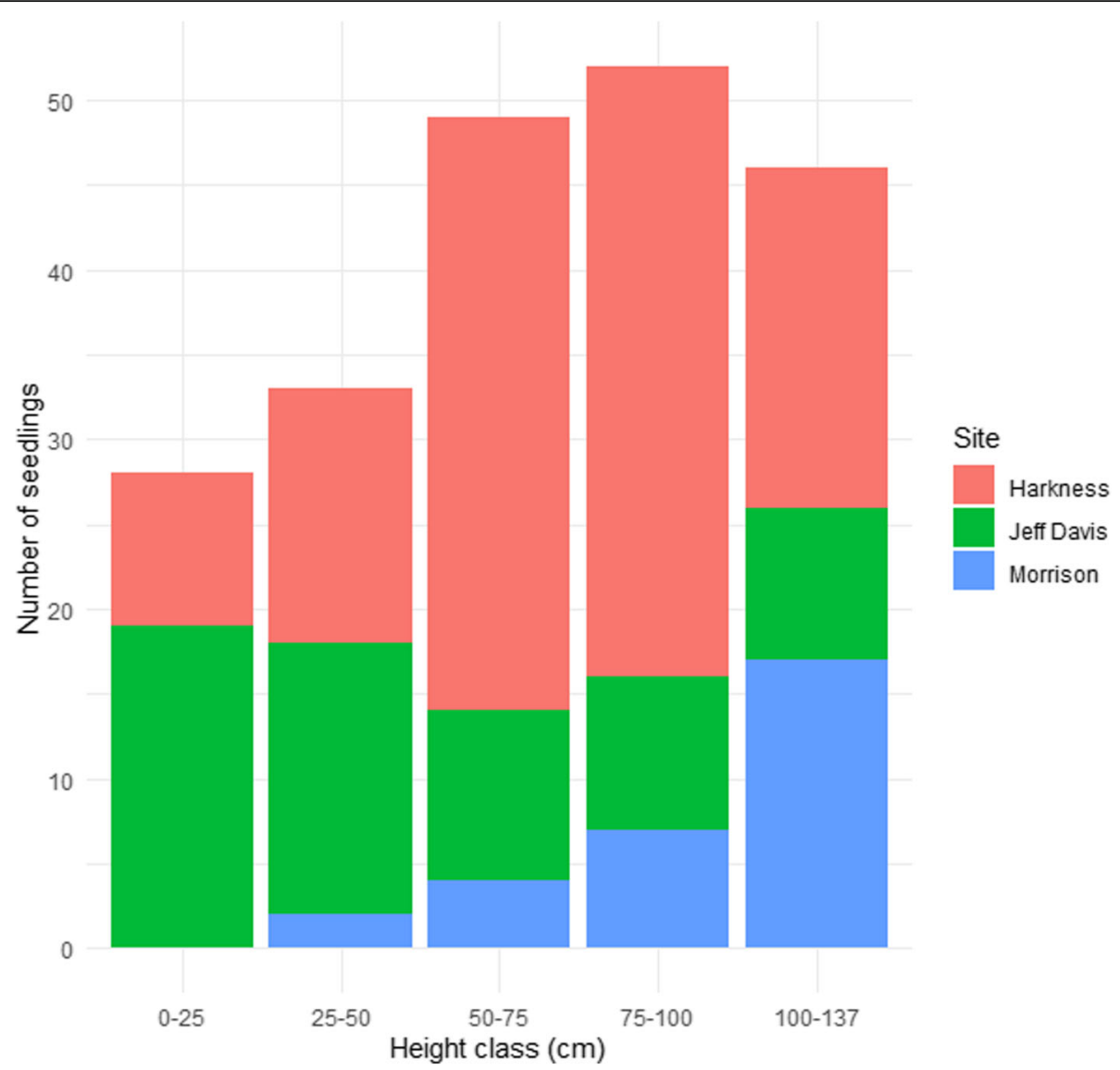

Fig. 6 Count data (number ha ${ }^{-1}$ ) for whitebark pine seedlings ( $<1.37 \mathrm{~m}$ tall) sampled on the lower sagebrush grassland belt transects across all three sites where data was collected during the 2017and 2018 field seasons in southwest Montana, USA

management. Further investigation is needed in other areas within whitebark pine's range to determine if our measured trend is widespread and if other species follow this same expansion downward in elevation. Caution should be used when applying climate change projections into land management decisions by fully recognizing the uncertainty of future climate projections and the great complexity of forested ecosystems. This case study serves as evidence of that uncertainty in climate change vegetation response projections.

\section{Acknowledgements}

We would like to extend our appreciation to E. Guiberson of the Dillon office Bureau of Land Management for collaborating on sites and project design, as well as Hansen Livestock for allowing access through their land. We would also like to thank the Rocky Mountain Research Station Fire Sciences Laboratory field crew members for their help in locating sites and data collection: M. Retzlaff, M. Reitz, C. Shane, F. Leary, and I. Gray.

\section{Authors' contributions}

SJF performed the fieldwork, analyzed the data, and wrote the paper. REK designed the study, wrote the study plan, assisted in data analysis, and helped write the paper. Both authors read and approved the manuscript.

\section{Funding}

This project was possible due to primary funding from the Bureau of Land Management Dillon Field Office. The project was co-funded by the National Fire Plan and the Rocky Mountain Research Station.

\section{Availability of data and materials}

Data collected in this study are available from the authors and it will be archived to a permanent web site in 2020.

\section{Ethics approval and consent to participate}

Not applicable.

\section{Consent for publication}

Not applicable.

\section{Competing interests}

The authors declare that they have no competing interests

Received: 31 January 2019 Accepted: 24 October 2019

Published online: 05 December 2019

\section{References}

Abatzoglou, J.T., and A.P. Williams. 2016. Impact of anthropogenic climate change on wildfire across western US forests. Proceedings of the National Academy of Sciences 113: 11770-11775 https://doi.org/10.1073/pnas. 1607171113.

Allen, C.D., A.K. Macalady, H. Chenchouni, D. Bachelet, N. McDowell, M. Vennetier, T. Kitzberger, A. Rigling, D.D. Breshears, E.H.(.T.). Hogg, P. Gonzalez, R. Fensham, Z. Zhang, J. Castro, N. Demidova, J.H. Lim, G. Allard, S.W. Running, 
A. Semerci, and N. Cobb. 2010. A global overview of drought and heatinduced tree mortality reveals emerging climate change risks for forests. Forest Ecology and Management 259: 660-684 https://doi.org/10.1016/j. foreco.2009.09.001.

Arno, S.A. 2001. Community types and natural disturbance processes. In Whitebark pine communities: ecology and restoration, ed. D.F. Tomback, S.A. Arno, and R.E. Keane, 74-89. Washington, D.C.: Island Press.

Arno, S.F. 1986. Whitebark pine cone crops-a diminishing source of wildlife food? Western Journal of Applied Forestry 1: 92-94 https://doi.org/10.1093/ wjaf/1.3.92.

Arno, S.F., and G.E. Gruell. 1983. Fire history at the forest-grassland ecotone in southwestern Montana. Journal of Range Management 36(3):332-336 https:// doi.org/10.2307/3898481.

Arno, S.F., and R.J. Hoff. 1990. Pinus albicaulis Engelm. Whitebark pine. In: Silvics of North America. Volume I: conifers. Agriculture Handbook 654, ed. R.M. Burns and B.H. Honkala, technical editors, 268-279. Washington, D.C.: US Department of Agriculture, Forest Service.

Arno, S.F., E.D. Reinhardt, and J.H. Scott. 1993. Forest structure and landscape patterns in a subalpine lodgepole pine type: a procedure for quantifying past and present conditions. USDA Forest Service General Technical Report INT-294. Ogden: USDA Forest Service, Intermountain Research Station.

Arno, S.F., and T. Weaver. 1990. Whitebark pine community types and their patterns on the landscape. In: Proceedings_-symposium on whitebark pine ecosystems: ecology and management of a high-mountain resource; 1989 March 29-31, Bozeman, MT. USDA Forest Service General Technical Report INT270, Compiled by W.C. Schmidt and KJ. McDonald, 97-105. Ogden: USDA Forest Service, Intermountain Research Station. https://doi.org/10.2737/INTGTR-270

Ashton, I.W. 2010. Observed and projected ecological response to climate change in the Rocky Mountains and Upper Columbia Basin: a synthesis of current scientific literature. Natural Resource Report NPS/ROMN/NRR-2010/ 220. Fort Collins: National Park Service.

Belotelov, N.V., B.G. Bogatyrev, A.P. Kirilenko, and S.V. Venevsky. 1996. Modelling of time-dependent biome shifts under global climate changes. Ecological Modelling 87: 29-40 https://doi.org/10.1016/0304-3800(94)00200-2.

Callaway, R.M., E.H. DeLucia, D. Moore, R. Nowak, and W.H. Schlesinger. 1996. Competition and facilitation: contrasting effects of Artemisia tridentata on desert vs. montane pines. Ecology 77 (7): 2130-2141 https://doi.org/10.2307/ 2265707.

Carroll, A.L., S.W. Taylor, J. Régnière, and L. Safranyik. 2003. Effects of climate change on range expansion by the mountain pine beetle in British Columbia. In: Proceedings of the mountain pine beetle symposium: challenges and solutions, October 30-31, 2003, Kelowna, British Columbia, Canada. Information Report BC-X-399, ed. T.L. Shore, J.E. Brooks, and J.E. Stone, 223232. Victoria: Natural Resources Canada, Canadian Forest Service, Pacific Forestry Centre.

Chang, T., A.J. Hansen, and N. Piekielek. 2014. Patterns and variability of projected bioclimatic habitat for Pinus albicaulis in the Greater Yellowstone Area. PLoS ONE 9: e111669 https://doi.org/10.1371/journal.pone.0111669.

Dullinger, S., T. Dirnböck, and G. Grabherr. 2004. Modelling climate change-driven treeline shifts: relative effects of temperature increase, dispersal and invasibility. Journal of Ecology 92: 241-252 https://doi.org/10.1111/j.00220477.2004.00872.x.

Flannigan, M.D., M.A. Krawchuk, W.J. de Groot, B.M. Wotton, and L.M. Gowman. 2009. Implications of changing climate for global wildland fire. International Journal of Wildland Fire 18: 483-507 https://doi.org/10.1071/WF08187.

Goeking, S.A., and D.K. Izlar. 2018. Pinus albicaulis Engelm. (whitebark pine) in mixed-species stands throughout its US range: broad-scale indicators of extent and recent decline. Forests 9(3): 131 https://doi.org/10.3390/f9030131.

Hansen, A., K. Ireland, K. Legg, R. Keane, E. Barge, M. Jenkins, and M. Pillet. 2016. Complex challenges of maintaining whitebark pine in Greater Yellowstone under climate change: a call for innovative research, management, and policy approaches. Forests 7 (3): 54 https://doi.org/10.3390/f7030054.

Hansen, A.J., and L.B. Phillips. 2015. Which tree species and biome types are most vulnerable to climate change in the US Northern Rocky Mountains? Forest Ecology and Management 338: 68-83 https://doi.org/10.1016/j. foreco.2014.11.008.

Heyerdahl, E.K., R.F. Miller, and R.A. Parsons. 2006. History of fire and Douglas-fir establishment in a savanna and sagebrush-grassland mosaic, southwestern Montana, USA. Forest Ecology and Management 230: 107-118 https://doi.org/ 10.1016/j.foreco.2006.04.024
Iglesias, V., T.R. Krause, and C. Whitlock. 2015. Complex response of white pines to past environmental variability increases understanding of future vulnerability. PLoS ONE 10 (4): e0124439 https://doi.org/10.1371/journal.pone.0124439.

Jensen, M.E., W.J. Hann, R.E. Keane, J. Caratti, and P.S. Bourgeron. 1994. ECODATA - a multiresource database and analysis system for ecosystem description and evaluation. In: Eastside forest ecosystem health assessment. Volume II: ecosystem management: principles and applications. USDA Forest Service General Technical Report PNW-GTR-318, technical editing by M.E. Jensen and P.S. Bourgeron, 192-205. Portland: USDA Forest Service, Pacific Northwest Research Station. https://doi.org/10.2737/PNW-GTR-318.

Johnstone, J.F., and F.S. Chapin. 2003. Non-equilibrium succession dynamics indicate continued northern migration of lodgepole pine. Global Change Biology 9 (10): 1401-1409 https://doi.org/10.1046/j.1365-2486.2003.00661.x.

Keane, R.E. 2001. Can the fire-dependent whitebark pine be saved? Fire Management Today 61 (3): 17-20.

Keane, R.E., K.L. Gray, and L.J. Dickinson. 2007. Whitebark pine diameter growth response to removal of competition. USDA Forest Service Research Note RMRS-RN-32. Fort Collins: USDA Forest Service, Rocky Mountain Research Station https://doi.org/10.2737/RMRS-RN-32.

Keane, R.E., L.M. Holsinger, M.F. Mahalovich, and D.F. Tomback. 2017. Evaluating future success of whitebark pine ecosystem restoration under climate change using simulation modeling. Restoration Ecology 25: 220-233 https:// doi.org/10.1111/rec.12419.

Keane, R.E., M.F. Mahalovich, B.L. Bollenbacher, M.E. Manning, R.A. Loehman, T.B. Jain, L.M. Holsinger, and A.J. Larson. 2018. Effects of climate change on forest vegetation in the Northern Rockies. In: Climate change and Rocky Mountain ecosystems. Advances in global change research, volume 63, ed. J. Halofsky and D. Peterson, 59-95. Cham: Springer https://doi.org/10.1007/978-3-319-56928-4_5.

Keane, R.E., D.F. Tomback, C.A. Aubry, A.D. Bower, E.M. Campbell, C.L. Cripps, M.B. Jenkins, M.F. Mahalovich, M. Manning, S.T. McKinney, M.P. Murray, D.L. Perkins, D.P. Reinhart, C. Ryan, A.W. Schoettle, and C.M. Smith. 2012. A rangewide restoration strategy for whitebark pine forests. USDA Forest Service General Technical Report RMRS-GTR-279. Fort Collins: USDA Forest Service, Rocky Mountain Research Station https://doi.org/10.2737/RMRS-GTR-279.

Kendall, K.C., and R.E. Keane. 2001. Whitebark pine decline: infection, mortality, and population trends. In: Whitebark pine communities: ecology and restoration, ed. D.F. Tomback, S.F. Arno, and R.E. Keane, 221-242. Washington, D.C.: Island Press.

Koteen, L. 2002. Climate change, whitebark pine, and grizzly bears in the Greater Yellowstone ecosystem. In: Wildlife responses to climate change: North American case studies, ed. S.H. Schneider and T.L. Root, 343-414. Washington, D.C.: Island Press.

Landguth, E.L., Z.A. Holden, M.F. Mahalovich, and S.A. Cushman. 2017. Using landscape genetics simulations for planting blister rust resistant whitebark pine in the US Northern Rocky Mountains. Frontiers in Genetics 8: 9 https:// doi.org/10.3389/fgene.2017.00009.

Larson, E.R. 2009. Status and dynamics of whitebark pine (Pinus albicaulis Engelm.) forests in southwest Montana, central Idaho, and Oregon, USA. Dissertation, University of Minnesota, Twin Cities Campus, Minnesota, USA.

Laycock, W.A. 1991. Stable states and thresholds of range condition on North American rangelands: a viewpoint. Journal of Range Management 44 (5): 427-433 https://doi.org/10.2307/4002738.

Lesica, P., S.V. Cooper, and G. Kudray. 2007. Recovery of big sagebrush following fire in southwest Montana. Rangeland Ecology \& Management 60 (3): 261-269 https://doi.org/10.2111/1551-5028(2007)60[261:ROBSFF]2.0.CO;2.

Loehman, R.A., J.A. Clark, and R.E. Keane. 2011. Modeling effects of climate change and fire management on western white pine (Pinus monticola) in the northern Rocky Mountains, USA. Forests 2 (4): 832-860 https://doi.org/10. 3390/ 2040832.

Lonergan, E.R., C.L. Cripps, and C.M. Smith. 2013. Influence of site conditions, shelter objects, and ectomycorrhizal inoculation on the early survival of whitebark pine seedlings planted in Waterton Lakes National Park. Forest Science 60 (3): 603-612 https://doi.org/10.5849/forsci.13-511.

Lutes, D.C., N.C. Benson, M. Keifer, J.F. Caratti, and S.A. Streetman. 2009. FFI: a software tool for ecological monitoring. International Journal of Wildland Fire 18 (3): 310-314 https://doi.org/10.1071/WF08083.

Lutes, D.C., R.E. Keane, J.F. Caratti, C.H. Key, N.C. Benson, S. Sutherland, and L.J. Gangi. 2006. FIREMON: Fire effects monitoring and inventory system. USDA Forest Service General Technical Report RMRS-GTR-164-CD. Fort Collins: USDA Forest Service, Rocky Mountain Research Station https://doi.org/10. 2737/RMRS-GTR-164 
Matthews, S.N., L.R. Iverson, A.M. Prasad, M.P. Peters, and P.G. Rodewald. 2011. Modifying climate change habitat models using tree species-specific assessments of model uncertainty and life history-factors. Forest Ecology and Management 262 (8): 1460-1472 https://doi.org/10.1016/j.foreco.2011.06.047.

McKinney, S.T. 2004. Evaluating natural selection as a management strategy for restoring whitebark pine. Thesis, University of Colorado, Denver, USA.

Millar, C.I., R.D. Westfall, D.L. Delany, M.J. Bokach, A.L. Flint, and L.E. Flint. 2012. Forest mortality in high-elevation whitebark pine (Pinus albicaulis) forests of eastern California, USA; influence of environmental context, bark beetles, climatic water deficit, and warming. Canadian Journal of Forest Research 42 (4): 749-765 https://doi.org/10.1139/x2012-031.

Mohatt, K.R., C.L. Cripps, and M. Lavin. 2008. Ectomycorrhizal fungi of whitebark pine (a tree in peril) revealed by sporocarps and molecular analysis of mycorrhizae from treeline forests in the Greater Yellowstone ecosystem. Botany 86 (1): 14-25.

Pfister, R.D., B.L. Kovalchik, S.F. Arno, and R.C. Presby. 1977. Forest habitat types of Montana. USDA Forest Service General Technical Report INT-GTR-34. Ogden: USDA Forest Service, Intermountain Forest and Range Experiment Station.

Schneiderman, J.E., H.S. He, F.R. Thompson, W.D. Dijak, and J.S. Fraser. 2015. Comparison of a species distribution model and a process model from a hierarchical perspective to quantify effects of projected climate change on tree species. Landscape Ecology 30 (10): 1879-1892 https://doi.org/10.1007/s10980-015-0217-1.

Schoennagel, T., J.K. Balch, H. Brenkert-Smith, P.E. Dennison, B.J. Harvey, M.A. Krawchuk, N. Mietkiewicz, P. Morgan, M.A. Moritz, R. Rasker, M.G. Turner, and C. Whitlock. 2017. Adapt to more wildfire in western North American forests as climate changes. Proceedings of the National Academy of Sciences 114 (18): 4582-4590 https://doi.org/10.1073/pnas.1617464114.

Singer, A., K. Johst, T. Banitz, M.S. Fowler, J. Groeneveld, A.G. Gutiérrez, F. Hartig, R. M. Krug, M. Liess, G. Matlack, K.M. Meyer, G. Pe'er, V. Radchuk, A.-J. VoinopolSassu, and J.M.J. Travis. 2016. Community dynamics under environmental change: how can next generation mechanistic models improve projections of species distributions? Ecological Modelling 326: 63-74 https://doi.org/10. 1016/j.ecolmodel.2015.11.007.

Tomback, D.F. 1978. Foraging strategies of Clark's nutcracker. Living Bird 16: 123-161.

Tomback, D.F. 1982. Dispersal of whitebark pine seeds by Clark's nutcracker: a mutualism hypothesis. Journal of Ecology 51 (2): 451-467 https://doi.org/10.2307/3976.

Tomback, D.F. 1986. Post-fire regeneration of krummholz whitebark pine: a consequence of nutcracker seed caching. Madroño 33 (2): 100-110.

Tomback, D.F. 1998. Clark's nutcracker (Nucifraga columbiana), version 2.0. In: The Birds of North America, ed. A.F. Poole and F.B. Gill. Ithica: Cornell Lab of Ornithology https://doi.org/10.2173/bna.331.

Warwell, M.V., G.E. Rehfeldt, and N. Crookston. 2007. Modeling contemporary climate profiles of whitebark pine (Pinus albicaulis) and predicting responses to global warming. In: Proceedings of the conference-whitebark pine: a Pacific Coast perspective. R6-NR-FHP-2007-01, ed. E. Goheen, 139-142. Ashland: USDA Forest Service.

Westoby, M., B. Walker, and I. Noy-Meir. 1989. Opportunistic management for rangelands not at equilibrium. Journal of Range Management 42 (4): 266-274 https://doi.org/10.2307/3899492.

Wong, C.M., and L.D. Daniels. 2016. Novel forest decline triggered by multiple interactions among climate, an introduced pathogen and bark beetles. Global Change Biology 23 (5): 1926-1941 https://doi.org/10.1111/gcb.13554.

Wyka, S.A., I.A. Munck, N.J. Brazee, and K.D. Broders. 2018. Response of eastern white pine and associated foliar, blister rust, canker and root rot pathogens to climate change. Forest Ecology and Management 423: 18-26 https://doi. org/10.1016/j.foreco.2018.03.011

\section{Publisher's Note}

Springer Nature remains neutral with regard to jurisdictional claims in published maps and institutional affiliations.

\section{Submit your manuscript to a SpringerOpen ${ }^{\circ}$ journal and benefit from:}

- Convenient online submission

- Rigorous peer review

- Open access: articles freely available online

- High visibility within the field

- Retaining the copyright to your article

Submit your next manuscript at $\boldsymbol{\nabla}$ springeropen.com 